\title{
Assessment ups the ante on climate change
}

Quirin Schiermeier, Munich

Global warming is liable to become an even more acute problem than anticipated, according to the new assessment of the Intergovernmental Panel on Climate Change (IPCC).

Whereas global average-surface temperature has increased by $0.6^{\circ} \mathrm{C}$ during the past century, it is set to rise by between $1.4^{\circ} \mathrm{C}$ and $5.8^{\circ} \mathrm{C}$ by 2100 , according to the report. There is "new and stronger evidence" that global warming is caused by human activities, it adds.

"The projected rate of warming is much larger than the observed changes during the twentieth century and is very likely to be without precedent during at least the last 10,000 years, based on palaeoclimate data," it says.

The report was finalized and unanimously accepted last week in Shanghai by 150 scientists and government representatives of the IPCC's working group on the science of climate change. The working group's third assessment report (the first two were published in 1990 and 1995) was three years in the making, involving 123 lead authors from around the world, and more than 500 contributing authors.
The new estimation of the probable range of global warming differs considerably from that in the 1995 report, which had projected a maximum temperature rise of $3.5^{\circ} \mathrm{C}$. The new projection - almost the same as the figures leaked to the press last October - is based on advances in climate modelling and on data that have become available from empirical work since 1995.

But the authors of the report remained cautious about detailed predictions of possible climate instabilities on a more regional scale. Frequency and intensity of extreme local weather events, such as hurricanes and heavy rainfall, have been excluded from the projection, owing to "scientific uncertainties". New research on possible discontinuities in the ocean circulation, such as a shutoff of the thermohaline circulation of the North Atlantic (see Nature 409, 153-158; 2001), was also left unconsidered.

The report arrives after international talks last November failed to reach agreement on implementing the 1997 Kyoto Protocol to reduce greenhouse-gas emissions.

John Houghton, co-chair of the IPCC working group on the scientific assessment

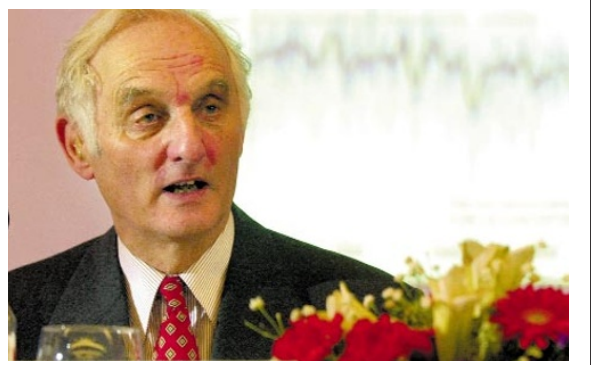

Stern warning: John Houghton unveils the revised predictions on global warming.

of climate change, is happy that the "serious news" of the report was accepted by the representatives of governments, including the United States and Saudi Arabia, which, in the past, had been reluctant to accept evidence for man-made climate change.

"It is now widely undisputed that the increased intensity of the hydrological cycle will lead to a rise in sea levels, and, in some regions, to more frequent floods and droughts," Houghton says. "I hope that this insight will do a great deal to convince governments that actions further to the Kyoto Protocol are urgently needed.”

\section{Demand for physicists on the rise}

\section{Alison Abbott, Munich}

What becomes of research students who study the fundamental forces of the Universe? According to a survey of students who pass through CERN, the European Laboratory for Particle Physics, esotericism proves no bar to lucrative employment.

Half of the 700 students surveyed landed well-paid jobs in high-tech industries, and the other half stayed employed in academic research. None were left looking for work.

The survey confirms other indications that physicists are in demand in the private sector, says Alex Bradshaw, vice-president of the German Physical Society. The society has been warning for several years that there will soon be a shortage of physics graduates. Fear of unemployment is believed to be one of the reasons fewer students have enrolled in the physical sciences in Europe during the past decade.

The CERN survey tracked students from 19 countries who worked on Delphi, one of four major particle detectors on CERN's Large Electron-Positron collider. Whereas, in $1996,4.8 \%$ of students were without a job immediately after graduation, zero unemployment was recorded in 2000 . The percentage of those employed in the private sector increased from $43 \%$ to about $50 \%$ during these five years.
"High-tech industries want to acquire the practical skills that students learn at CERN," says Tiziano Camporesi, spokesman for the Delphi experiment.

The survey also showed that the number of female students on the experiment increased over the years to $20 \%$, and that they followed the same early career paths, with the same levels of responsibility, as the male students.

Bradshaw hopes that the experience of students at CERN will encourage more interest in physics among school-leavers. An upturn appears to have already started, he says, with a significantly increased enrolment in university physics programmes in Germany this year.

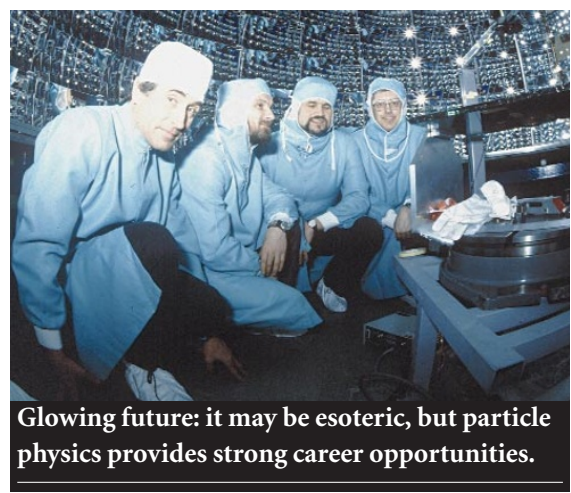

\section{Stem-cell research to start in Britain}

\section{David Dickson, London}

British scientists have been given the goahead to carry out research on cloned human embryos aimed at the treatment of diseases. Such research - which is likely to remain outlawed in most of the rest of Europe - could now begin in Britain before the end of the year.

On Monday, the House of Lords voted to approve the government's proposal that such research should be allowed under the Human Fertilization and Embryology Act. A similar vote was passed last month by the House of Commons (see Nature 409,$5 ; 2001$ ), and scientists will be able to apply for licences for the research shortly.

The margin of the vote in the Lords where the proposed amendment was approved by 212 votes to 92 - surprised observers who had anticipated a closer vote, particularly in the light of calls for caution from religious leaders, including the Archbishop of Canterbury, the head of the Church of England.

Some critics appear to have been mollified by a Lords' plan to set up a committee to review the ethical issues that the research raises. The government has also promised to introduce "as soon as possible" a bill to ban reproductive cloning. 